\title{
Reflexões metodológicas sobre Cartografia Escolar, Multimodalidade e Multiletramentos com foco de análise na Educação Básica
}

\author{
Methodological reflections on School Cartography, Multimodality and Multilevels with focus of \\ analysis in Basic Education
}

\begin{abstract}
Natália Lampert Batista
Pós doutoranda em Geografia na Universidade Federal de Santa Maria, Brasil natilbatista3@gmail.com

Elsbeth Léia Spode Becker Professora Dra ${ }^{\mathrm{a}}$. do Mestrado de Ensino de Humanidades e Linguagens Universidade Franciscana, Brasil elsbeth.geo@gmail.com

Roberto Cassol Professor Dr. do Programa de Pós-graduação em Geografia Universidade Federal de Santa Maria, Brasil rtocassol@gmail.com
\end{abstract}

\section{Resumo}

Os mapas são uma das primeiras formas de linguagem utilizadas pela humanidade para se comunicar e para registrar informações sobre o espaço vivido. Essa linguagem inicialmente esteve atrelada basicamente à representação analógica da realidade. Porém, com a evolução tecnológica empreendida no universo da Cartografia e com a transformação da sociedade, especialmente nos séculos XX e XXI, essa linguagem se tornou múltipla e diversa, ou seja, multimodal e híbrida necessitando ser debatida enquanto uma nova possibilidade de inovação metodológica no ensino de Geografia. Sob essa lógica, o presente texto teve como objetivos relatar uma metodologia de multiletramentos para Cartografia Escolar que enfatiza a existência de mapas híbridos e multimodais e que fornece subsídios às práticas pedagógicas multiletradas no ensino de Geografia na Educação Básica. Concluiu-se que a proposta metodológica articulou os conhecimentos de Cartografia Escolar, as novas e múltiplas linguagens e o ensino de Geografia se mostrando eficiente nos contextos de aplicação e auxiliando com a aprendizagem dos estudantes de forma interativa e colaborativa no Ensino Fundamental e no Ensino Médio da Educação Básica.

Palavras-chave: Ensino de Geografia. Softwares livres. Relato metodológico.

\begin{abstract}
Maps are one of the first forms of language used by mankind to communicate and record information about lived space. This language was basically linked to the analogical representation of reality. However, with the technological evolution undertaken in the Cartography universe and with the transformation of society, especially in the XX and XXI centuries, this language has become multiple and diverse, that is, multimodal and hybrid, needing to be debated as a new possibility of methodological innovation in the Geography teaching. Under this logic, the present text had as objectives to report a methodology of multiletramentos for School Cartography that emphasizes the existence of hybrid and multimodal maps and that provides subsidies to the pedagogical practices multiletradas in the teaching of Geography in Basic Education. It was concluded that the methodological proposal articulated the knowledge of School Cartography, the
\end{abstract}


new and multiple languages and the teaching of Geography being efficient in the contexts of application and that collaborating with the students' learning in an interactive and collaborative way in Elementary Education and Teaching Middle of Basic Education.

Keywords: Geography Teaching. Free software. Methodological report.

\title{
1. INTRODUÇÃO
}

O presente texto integra um dos capítulos da tese intitulada "Cartografia Escolar, multimodalidade e multiletramentos para o ensino de Geografia na contemporaneidade" que foi desenvolvida no Programa de Pós-graduação em Geografia (PPGGeo) da Universidade Federal de Santa Maria (UFSM), registrada no sob o $\mathrm{n}^{\circ} 042386$ no Gabinete de Projetos do CCNE/UFSM e possui CAAE $n^{\circ}$ 93880718.1.1001.5346, no CEP/UFSM e defendida em 19 de junho de 2019.

O problema de pesquisa observado é em que medida se pode compreender e aproximar as práticas cartográficas multiletradas, presentes nos softwares livres, aos conhecimentos da Cartografia Escolar no ensino de Geografia em sala de aula? Com base nesta proposição, levantouse como argumento de tese a discussão do conceito de mapa híbrido e multimodal ${ }^{1}$ destinado ao ensino de Geografia e à Cartografia Escolar na Educação Básica como base para o desenvolvimento da tese.

O conceito de multiletramentos essencial ao entendimento da metodologia foi proposto pelos pesquisadores do Grupo Nova Londres² e perpassa por dois entendimentos básicos: "por um lado à multiplicidade de linguagens, semioses e mídias envolvidas na criação de significação para os textos multimodais contemporâneos e por outro para a pluralidade e a diversidade cultural trazidas pelos autores-leitores contemporâneos a essa criação de significação" (ROJO, 2013, p.14).

Logo:

\begin{abstract}
No que se refere à multiplicidade de culturas, é preciso notar: [...] que os textos que hoje vemos a nossa volta são produções culturais letradas em efetiva circulação social, como um conjunto de textos híbridos de diferentes letramentos (vernáculas e dominantes), de diferentes campos (ditos "populares/de massa/eruditos"), desde sempre, híbridos, caracterizados por um processo de escolha pessoal e política e de hibridização de produções de diferentes "coleções" (ROJO, 2012, p. 13).
\end{abstract}

Já no que tange à multiplicidade de linguagens, modos ou semioses nos textos/mapas em circulação, refere-se às suas "novas" formas de produção, sistematização e apresentação (ROJO, 2012). Por conseguinte, a Pedagogia dos Multiletramentos apresenta características fortemente

\footnotetext{
${ }^{1}$ Mapa híbrido e multimodal pode ser conceituado como aquele que é composto por materializações e por relações, demonstrando suas intencionalidades e as múltiplas possibilidades de leituras de mundo de acordo com os interesses e conhecimentos dos estudantes-autores que processam, modificam e adaptam os bancos de dados cartográficos, remixam informações geográficas, sistematizam a produção cartográfica e a compartilham em distintos meios de comunicação através do uso da multimodalidade empregada em sua apresentação e em sua confecção.

${ }^{2}$ Grupo pioneiro nas pesquisas de multiletramentos, formado por pesquisadores dos Estados Unidos, da Inglaterra e da Austrália que percebiam signicativas transformações nos usos da linguagem e nas formas de ver e agir no mundo.
} 
vinculadas às "novas" organizações sociais e, de modo especial, às novas mídias e tecnologias que surgem e diversificam as formas de linguagem, diferenciando-as em múltiplas linguagens que permitem o uso dos mapas como fonte de entendimento do mundo (BATISTA; BECKER; CASSOL, 2018).

Os demais conceitos teóricos norteadores da pesquisa podem ser encontrados em Batista, Becker e Cassol (2018) ou em Batista (2019) e estão destacados na Nuvem Conceitual da Figura 01. Observa-se que a interação entre todos os conceitos como ensino de Geografia, Cartografia Escolar, multimodalidade, multiletramentos, Novas Tecnologias de Informação e Comunicação, alicerçadas nas novas características da sociedade contemporânea e nos anseios da Escola e do ensino de Geografia do século XXI, embasam a discussão das propostas metodológicas sob o delineamento do método cartográfico de Deleuze e Guattari (1995).

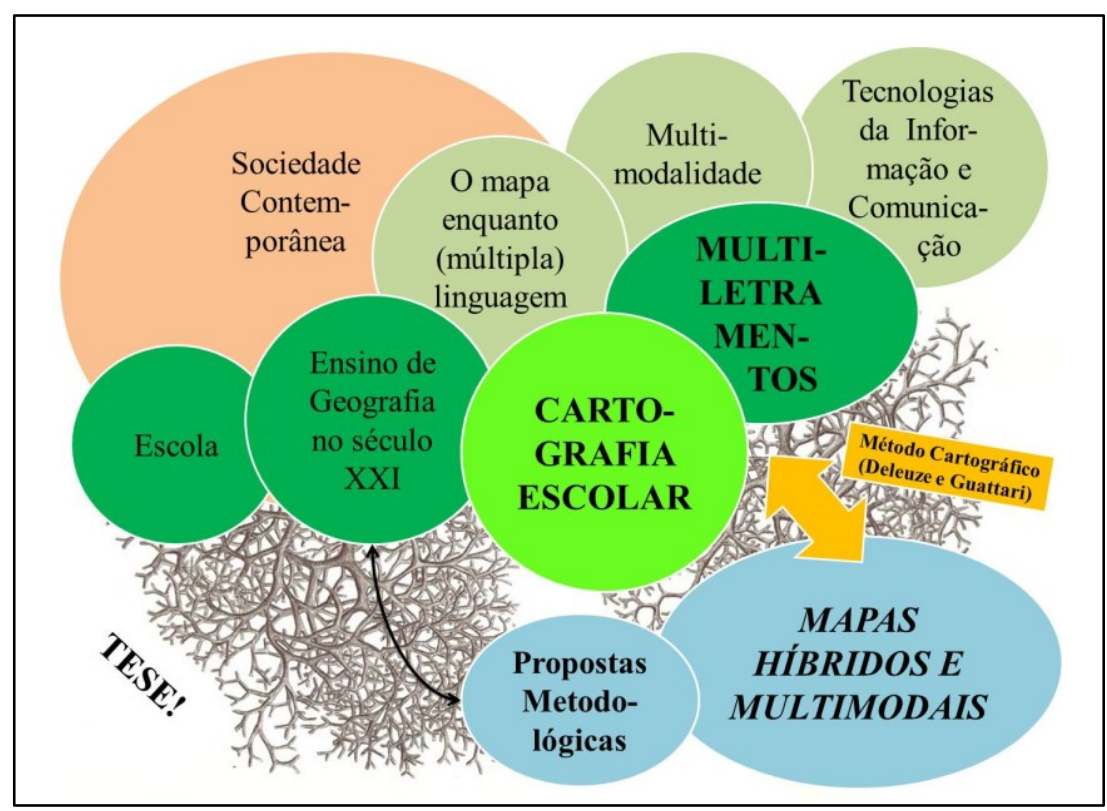

Figura 01 - Nuvem conceitual norteadora do trabalho desenvolvido na construção da proposta metodológica de Cartografia Escolar para o ensino de Geografia.

Sob essa lógica, o presente texto teve como objetivo relatar a metodologia de multiletramentos para Cartografia Escolar, desenvolvida e testada na Escola Municipal de Ensino Fundamental (EMEF) Junto ao CAIC Luizinho de Grandi e no Colégio Tiradentes da Brigada Militar, Santa Maria/RS, que enfatizem a existência de mapas híbridos e multimodais e que fornecem subsídios às práticas pedagógicas multiletradas no ensino de Geografia na Educação Básica.

\section{PONDERAÇÕES METODOLÓGICAS}

Metodologicamente, o estudo esteve embasado no método cartográfico de Deleuze e Guattari (1995) e apresenta o relato da aplicação e da avaliação da proposta metodológica de 
Cartografia Escolar para o ensino de Geografia desenvolvida na referida tese. Para o encaminhamento e aplicação da proposta, adotaram-se como campos de pesquisa duas Instituições de Ensino da Educação Básica de diferentes níveis, a saber: Ensino Fundamental e Ensino Médio. $\mathrm{Na}$ primeira se aplicou a atividade durante as aulas de Geografia e na segunda como proposta de Oficinas Pedagógicas em turno inverso ao das aulas dos estudantes. Optou-se pela estratégia de validação, pois o objetivo não consiste em comparar a assimilação dos estudantes frente à metodologia, mas sim compreender a eficácia da metodologia em diferentes etapas da Educação Básica e em distintos contextos e circunstâncias, seja de aplicação da proposta, seja aspectos educacionais e socioeconômicos (posteriormente destacados).

O fato de não priorizar a comparação pode e deve ser reforçado pela compreensão de que os níveis de abstração e de entendimento da proposta em diferentes níveis de ensino são diferenciados e diversos, e, assim, não cabem serem comparados nesta interface. Conforme pesquisa realizada por Rizzatti $(2018$, p. 54) é possível inferir que “[...] um aluno do Ensino Médio deve possuir mais habilidades cognitivas, logo, consegue extrair mais informações que um do Ensino Fundamental. Deste modo, o mapa apresentado para um discente do Ensino Médio pode possuir informações mais complexas se comparado ao Ensino Fundamental”.

\section{SOBRE OS PARTICIPANTES DA PESQUISA}

Escolheram-se como campo de pesquisa a EMEF Junto ao CAIC Luizinho de Grandi e o Colégio Tiradentes da Brigada Militar, localizadas, respectivamente, nos bairros Lorenzi e Nossa Senhora das Dores, na área urbana de Santa Maria/RS, como demostrado no mapa da Figura 2. A primeira Escola se encontra em um bairro com elevados índices de vulnerabilidade social e com um público alvo bem diversificado, pois há alunos carentes e outros com condições socioeconômicas mais elevadas. Esse contexto da Escola foi discutido por Batista, Feltrin e Becker (2019) e por Feltrin e Batista (2017) em outras oportunidades e pode ser ratificado pelos resultados apresentados neste artigo. Já o Colégio Tiradentes é uma instituição que abarca um público de classe média, sendo marcado por processos seletivos de ingresso na Instituição e por atrair estudantes de Santa Maria e de municípios vizinhos para estudarem na Instituição. Tal fato fica evidente quando se apresentam os bairros de residência dos estudantes do Colégio.

Com relação à descrição do corpus de pesquisa, realizou-se a aplicação de um questionário semiestruturado dividido em dois eixos: caracterização do perfil dos alunos e expectativas para o projeto. Assim, os estudantes apresentaram, de modo geral, a sua compreensão do que é relevante no ensino de Geografia e as suas expectativas para o projeto em desenvolvimento. Na sequência, as 
respostas foram apresentadas e discutidas com base nas observações do cotidiano das atividades desenvolvidas e no referencial teórico adotado na pesquisa.

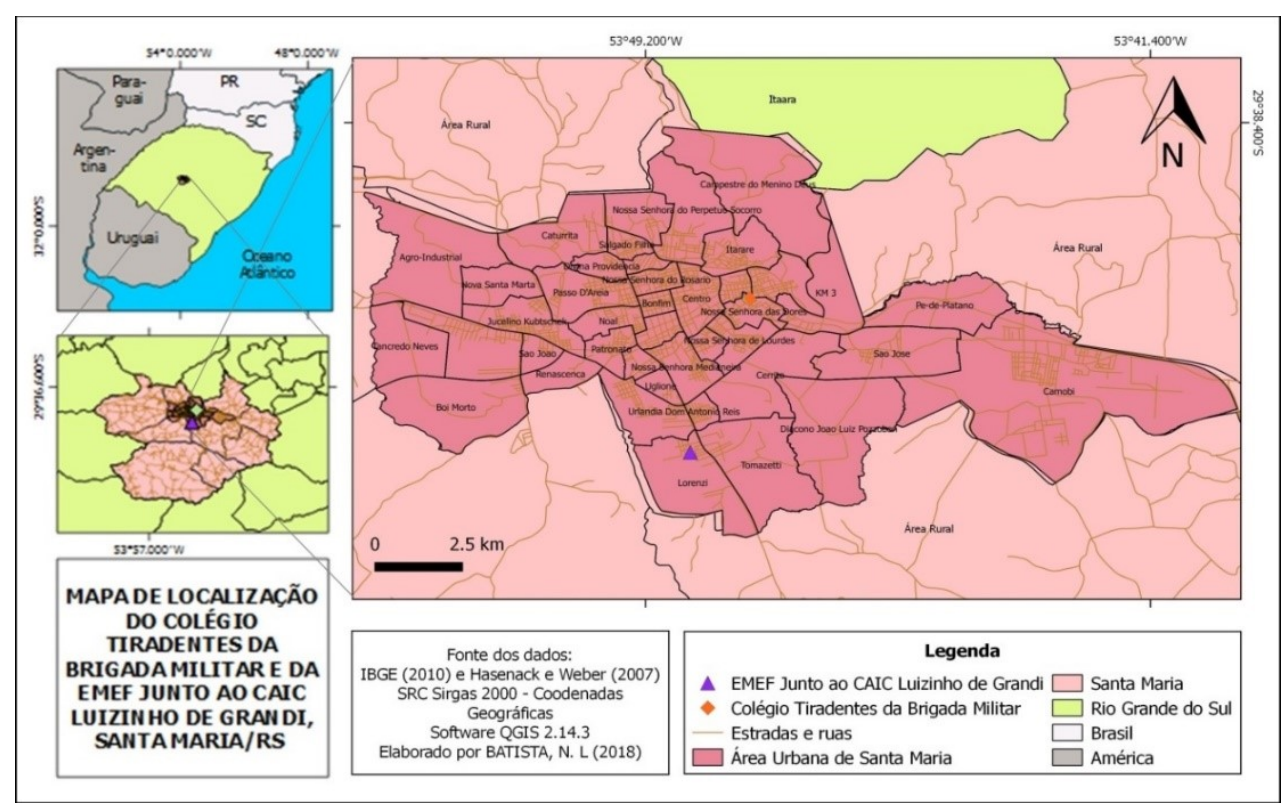

Figura 2 - Mapa de localização das escolas onde foi desenvolvida a pesquisa.

Fonte: Organização dos Autores, 2019.

Na EMEF Junto ao CAIC Luizinho de Grandi, contou-se com 39 alunos participantes na pesquisa, todos com Termo de Consentimento Livre e Esclarecido (TCLE) e Termo de Assentimento (TA) assinado pelos alunos e pelos seus responsáveis, tendo em vista que são menores de idade. Por serem aplicada nas aulas de Geografia, os demais estudantes das turmas foram convidados a desenvolverem a metodologia em conjunto com o corpus de pesquisa, porém não responderam nenhum dos questionários e foram desconsiderados na redação dos diários de campo. Optou-se por esse formato para que todos tivessem a oportunidade de interagir com a proposta metodológica, mas respeitando a individualidade dos estudantes que não foram autorizados e/ou não desejaram participar da pesquisa.

Com relação ao perfil dos participantes, observa-se nos gráficos da Figura 3a que a grande maioria dos estudantes $67 \%$ apresenta 12 e 13 anos, tal fato se refere à predominância de alunos de $7^{\mathrm{o}}$ ano na pesquisa ( $60 \%$ dos participantes). Já os demais estudantes predominantemente com 14 e 15 anos são oriundos da turma de $8^{\circ}$ ano que integrou a amostra de pesquisa. As turmas participantes da pesquisa foram escolhidas aleatoriamente com base na compatibilidade entre $\mathrm{o}$ horário das aulas de Geografia e a disponibilidade do Laboratório de Informática da Instituição para a aplicação da proposta sempre no mesmo dia da semana. Outra característica expressiva é que o número de meninas participantes da proposta que é consideravelmente maior que o de meninos (Figura 3b), porém isso se constitui como uma característica das turmas envolvidas no geral e não somente do corpus de pesquisa envolvido. 


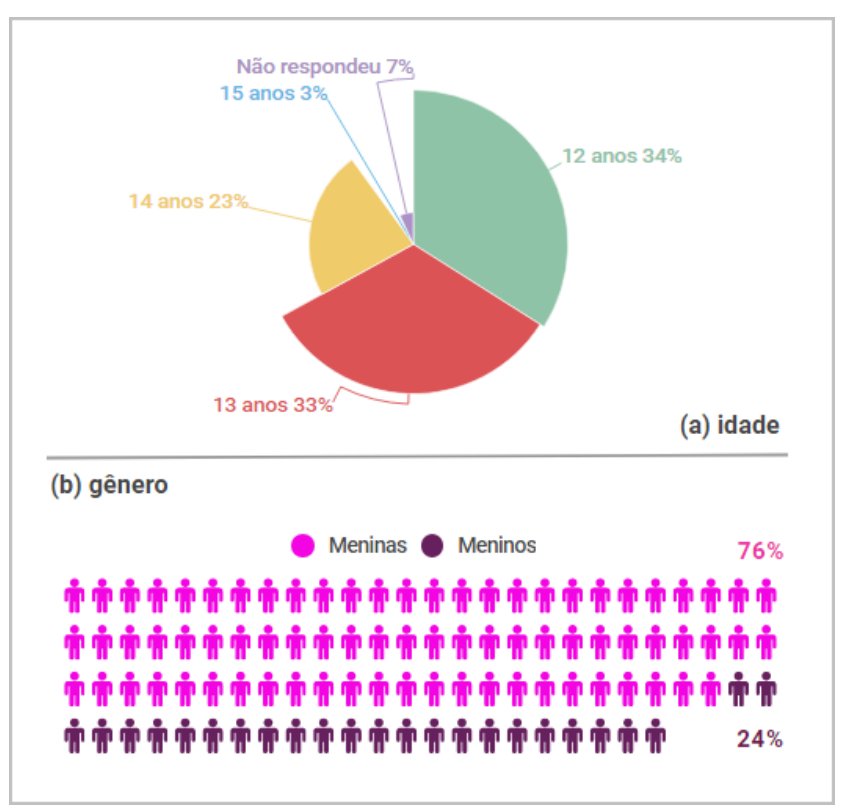

Figura 3 - Caracterização dos participantes: (a)Idade dos estudantes e (b) gênero.

Fonte: Questionário aplicado na EMEF Junto ao CAIC Luizinho de Grandi.

Dos integrantes da pesquisa, $21 \%$ dos estudantes já reprovaram alguma vez em sua vida escolar e 79\% mencionam que nunca reprovaram o que, associado à idade mencionada pelos alunos, comprova que a maioria dos alunos se encontra na debatida "idade certa escolar".

Quanto aos bairros de residência dos estudantes, eles destacam que moram no Lorenzi (onde está localizada a Escola) e no Tomazetti e no Dom Antônio Reis (bairros vizinhos ao bairro da Escola). Todos os estudantes apresentam um vínculo identitário muito significativo com o bairro de residência e no qual estudam. Isso reforça consideravelmente o seu desejo de aprender Geografia com base no seu espaço vivido e no mapeamento das realidades conhecidas. Muitos desses estudantes relatam terem ido poucas vezes ao Centro de Santa Maria/RS e quando vão, circulam predominantemente nas áreas comerciais desconhecendo pontos relevantes da história da cidade como "aquelas casas coloridas que eu só vejo na TV, nunca fui lá", mencionadas por um estudante $(\text { Vila Belga })^{4}$. Assim, o vínculo e a realidade que emergem no pensamento dos alunos é sempre a do bairro, constituindo um senso comum de referência e de interpretação do espaço, o que pode ser observado, posteriormente, quando se acessa o site construído pelos alunos.

Após essa caracterização geral dos estudantes, partiu-se para o entendimento de suas perspectivas frente à proposta de ensino, destacando as suas relações com a tecnologia, com o ensino de Geografia e com a Cartografia Escolar. Para introduzir o assunto, os alunos foram questionados sobre como costumam utilizar ferramentas tecnológicas e softwares no seu cotidiano.

\footnotetext{
${ }^{3}$ Consideramos que não há uma "idade certa" para aprender algo e que os tempos de aprendizagem são subjetivos e individuais, todavia não é isso que vem sendo apregoado nas legislações vigentes e, portanto, deve-se adotar essa concepção nas análises escolares.

${ }^{4}$ Vila Belga é uma unidade residencial localizada no bairro Centro, de Santa Maria, Rio Grande do Sul, Brasil, que está fortemente relacionada à Ferrovia que deu origem aos tempos áureos da cidade e se constitui como um marco histórico e turístico local.
} 
Obteve-se que a maioria tem acesso cotidianamente às ferramentas atreladas as tecnologias como celular, computador, Smart TV, entre outros. Assim, pode-se destacar que as tecnologias digitais “extrapolam os limites geográficos locais" (MAIA, 2013, p. 63) e aproximam o estudante da periferia das mídias e dos espaços globais. É uma nova realidade que contribui com a transformação das dinâmicas existentes no espaço, que diferencia as formas de interação e de trocas de informações e potencializa a atuação de educadores populares (FELTRIN; BATISTA, 2017).

Dessa forma, o acesso aos meios tecnológicos, especialmente, ao smartphone potencializa o acesso às mídias e a interação com a rede mundial de computadores, aproximando, a grande maioria dos contextos geográficos dos meios tecnológicos, como destacam Feltrin e Batista (2017), ao pesquisarem a realidade de aplicação da tese e que é corroborado pela Figura 4, a qual demostra que apenas 7\% dos alunos não acessam as tecnologias em seu cotidiano. Maia (2003) também destaca essa interface ao apontar que:

O urbano acaba sendo gradativamente reestruturado ao permitir que as tecnologias eletrônicas passem a ser usadas pela população em geral. E enganam-se aqueles que acreditam que os grupos da periferia não têm acesso as novas tecnologias e, mais especificamente, à internet. (MAIA, 2013, p. 62).

Para compreender melhor quais tecnologias e para qual finalidade são utilizadas pelos alunos, fez-se uma questão aberta em que eles deveriam destacar tais temas. Todos as respostas convergiram para tecnologias e ferramentas como: Televisão, Celular, Computador, Redes Sociais, Youtube, Netflix, Google. Já suas finalidades perpassam predominantemente por olhar filmes, conversar, estudar, entretenimento, pesquisas e informação, para pesquisar dúvidas, busca por “coisas que eu não sei” e curiosidades, conhecer novas coisas e pessoas, brincar, ouvir músicas e para realizar pesquisas escolares. Assim, observa-se que há múltiplos usos e finalidades no emprego tecnológico realizado pelos estudantes e que isso pode colaborar com a sua aprendizagem em diversos momentos.

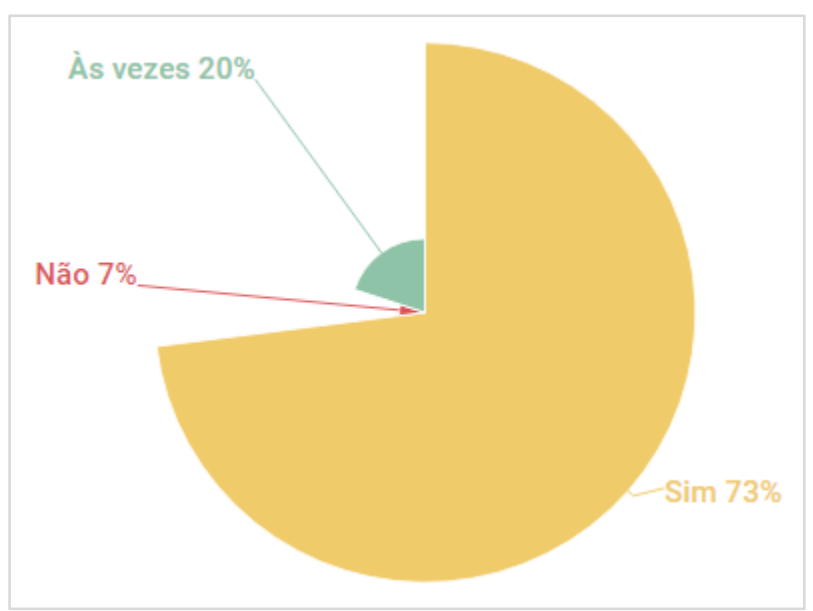

Figura 4 - Resposta à questão "Você costuma utilizar ferramentas/softwares tecnológicas/os no seu cotidiano?" Fonte: Questionário aplicado na EMEF Junto ao CAIC Luizinho de Grandi. 
Para direcionar essa questão com o tema da pesquisa em si, perguntou-se se os estudantes costumam encontram a presença de mapas nessas ferramentas/softwares, bem como para que comentassem livremente o seu uso de tecnologias. Verificou-se que nas ferramentas utilizadas (o que é coerente com o tipo de ferramentas mencionadas nas questões anteriores) muitos deles não observam a existência de mapas ou percebem em algumas ferramentas conforme demostrado na Figura 5.

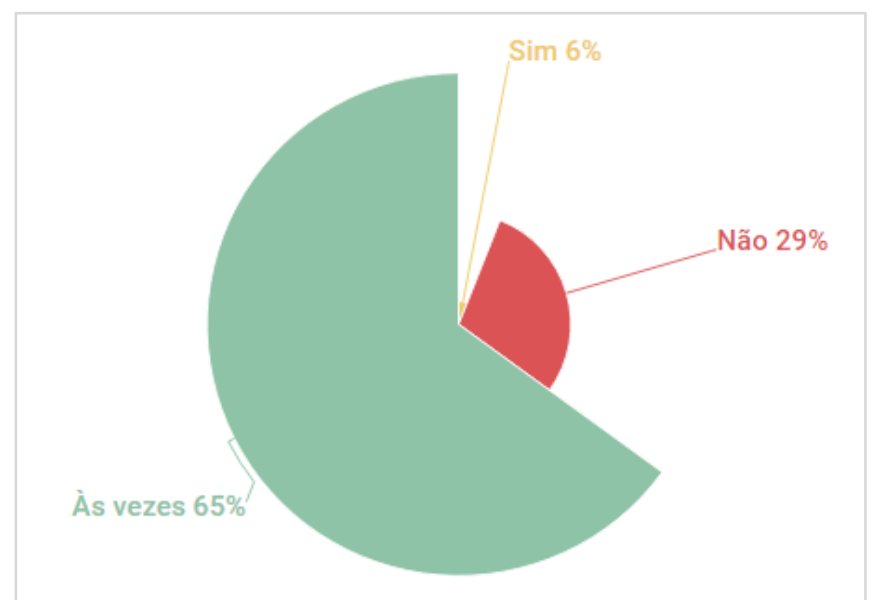

Figura 5 - Resposta à questão "Costuma observar a presença de mapas nessas ferramentas/softwares?" Fonte: Questionário aplicado na EMEF Junto ao CAIC Luizinho de Grandi.

Com relação ao uso das/os ferramentas/softwares os estudantes mencionam que: "Pelo celular nos podemos falar com pessoas e fazer pesquisas da Escola”; "Costumo usar para jogar, olhar vídeos, falar com meus amigos e saber da vida das pessoas"; "Para comunicação, diversão e notícias, também uso para postar fotos, ver vídeos e estudar”; "Não acesso todos os dias. Apenas para trabalhos da Escola e redes sociais"; "Eu vejo vídeo no Youtube, escuto músicas e mexo no Facebook"; e "Eu uso o Google Maps, principalmente quando eu vou viajar".

Observa-se que as finalidades de uso das tecnologias e softwares estão associadas à vida cotidiana dos estudantes e refletem os hábitos próprios das suas idades e focos de interesse. Após essa discussão mais geral sobre as tecnologias no cotidiano dos alunos, voltada ao embasamento do uso de mapas digitais e dos multiletramentos, partiu-se para a análise da compreensão prévia dos alunos sobre os mapas e a sua importância no dia a dia da população. Perguntou-se se os alunos percebem alterações nos mapas analógicos (tradicionais) em relação aos mapas digitais (atuais). As respostas foram diversas (Figura 6) e demostram uma grande variação nas concepções quanto à realidade dos mapas na contemporaneidade. 


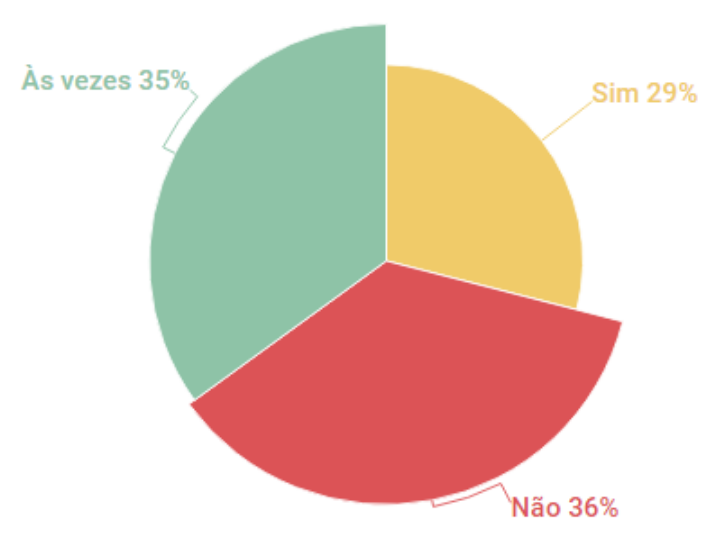

Figura 6 - Resposta à questão "Você percebe alterações nos mapas analógicos (tradicionais) em relação aos mapas atuais?"

Fonte: Questionário aplicado na EMEF Junto ao CAIC Luizinho de Grandi.

Os estudantes que apontaram que há diferenças nas formas de mapeamento foram convidados a destacar quais diferenças eles observam. Dentre as respostas compartilhadas se sobressaem: que os mapas atuais ou digitais "Melhoram a localização"; que "Eles ajudam bastante, mesmo com pouco texto e tem alguns mapas muito explicativos"; que é "Mais fácil o acesso, mais detalhado" nos mapas digitais; "Dá pra modificar o mapa e ampliar a tela” e isso "Facilita a visualização de algumas regiões e cidades"; "No digital fica mais nítido para ver" ao se referir sobre a resolução das imagens e a possibilidade de dar zoom no mapa; ressaltam que há "Mudança no papel das pessoas na construção dos mapas"; e que "alguns mapas são em papéis e outro são digitais".

Dos respondentes da pesquisa, 53\% apontam que os mapas são ferramentas importantes para a sua compreensão do lugar onde vivem, 28\% julgam que às vezes os mapas contribuem e 19\% não veem um papel importante nos mapas para a compreensão do espaço. Para evidenciar essa compreensão também se pediu para que destacassem se o uso de mapas afeta o modo como os estudantes compreendem o espaço em que estão inseridos, $64 \%$ julgam que sim, $33 \%$ que às vezes e $3 \%$ julgam que não afetam sua interpretação. Com relação às justificativas as suas respostas, tem-se que: com os mapas "é mais fácil se achar"; "porque ajudam saber onde estamos e onde vivemos"; "os mapas são importantes para nos localizarmos melhor e por que é importante saber onde estamos"; "Aqui onde eu moro não preciso de mapas"; "Para achar lugares que vou visitar"; ou ainda "Porque podemos marcar os lugares onde queremos ir". Assim, as concepções sobre os usos dos mapas remontam a localização e deslocamento no espaço.

Para o ensino de Geografia os estudantes foram convidados a destacar se é possível aprender mais por meio de mapas tecnológicos, devendo justificar as suas respostas. Obteve-se que "Sim, porque o ensino e a aprendizagem ficam mais fáceis"; "A Geografia ensina muitas coisas sobre os lugares onde moramos e os mapas nos auxiliam para nos acharmos no espaço"; "Sim, 
porque nos ajuda aprender mais e em menos tempo"; "Nos ajuda a ter um olhar mais exploratório e detalhado"; "Em alguns assuntos sim, mas em outros prefiro aulas normais"; "Prefiro mapas em folhas de Xerox. Eu acho eles mais fáceis"; "Sim, porque hoje em dia as tecnologias estão em tudo e é mais fácil nos localizarmos e entendermos"; "Sim, porque hoje em dia esse método é mais eficiente e econômico"; "O tecnológico facilita muito a vida, especialmente pra fazer os mapas”; e "Sim, eu acho muito interessante irmos na sala de informática é mais divertido e diferente".

Constata-se que há uma convergência para o fato de que os mapas associados às tecnologias podem colaborar significativamente com o processo de ensino e aprendizagem da Geografia. Todavia, percebe-se em dois relatos uma discordância com essa abordagem. O estudante que aponta que prefere os mapas em fotocópia, todavia, inclui o grupo de alunos que não tem uma relação direta com as tecnologias, o que de fato justificaria a sua dificuldade em compreender mapas que exigissem além da compreensão espacial uma alfabetização tecnológica, justificando assim a sua abordagem. Já o estudante que prefere "aulas normais" se pode inferir que esteja associado ao fato de que ao ser mapeador consciente e leitor crítico de mapas (ideias propostas por Simielli, 1999) os alunos precisam sair da zona de conforto e se posicionar criticamente frente a sua própria aprendizagem. Já nas “aulas normais" ou tradicionais do ensino de Geografia o estudante é um reprodutor de conhecimentos. Apenas memoriza e reproduz os temas apresentados pelo docente e isso tende a ser mais cômodo e exigir menos compreensão e dedicação na produção do próprio saber.

No Colégio Tiradentes da Brigada Militar, localizado no Bairro Nossa Senhora de Lourdes, o corpus de pesquisa contou com quinze alunos das três turmas de $1^{\circ}$ ano do Ensino Médio e o trabalho foi desenvolvido em turno inverso as aulas dos estudantes (tarde destinada a projetos pelo horário do Colégio). A idade predominante dos estudantes foi de 15 anos como pode ser observado no gráfico da Figura 6a e, ao contrário do que aconteceu na outra Escola, prevaleceu um maior número de meninos na atividade como destaca a Figura 6b. Observou-se que $22 \%$ dos estudantes já repetiram o ano e $78 \%$ dos alunos nunca repetiu, tais valores são muito aproximados da realidade da EMEF Junto ao CAIC Luizinho de Grandi, porém naquela, alguns alunos eram repetentes na própria série de aplicação da atividade e no Colégio Tiradentes todos os estudantes eram ingressantes e reprovaram apenas no Ensino Fundamental.

Quanto aos bairros de residência se observa maior variedade de locais, apesar do menor número de estudantes. Entre os bairros de residência destacaram-se: Juscelino Kubitschek, Camobi, Tomazetti, Nossa Senhora de Fátima, Centro e o distrito de Arroio Grande. Além disso, um integrante do corpus de pesquisa vinha de um município vizinho a Santa Maria/RS, a saber, de Itaara/RS. Isso remonta uma percepção espacial mais global. Os alunos conseguiam debater fatos que acontecem em toda a área urbana e rural de Santa Maria/RS e de outros municípios e Estados 
do Brasil. Tal fato pode ser associado a maior escolaridade dos alunos, a maior distância percorrida para chegar ao Colégio, bem como ao fato de que muitos sempre viajam em períodos de férias, por exemplo, com seus responsáveis, de acordo com relatos dos próprios estudantes que solicitaram informação para mapear outros lugares (que iriam conhecer ou viajar), além dos propostos pela pesquisa.

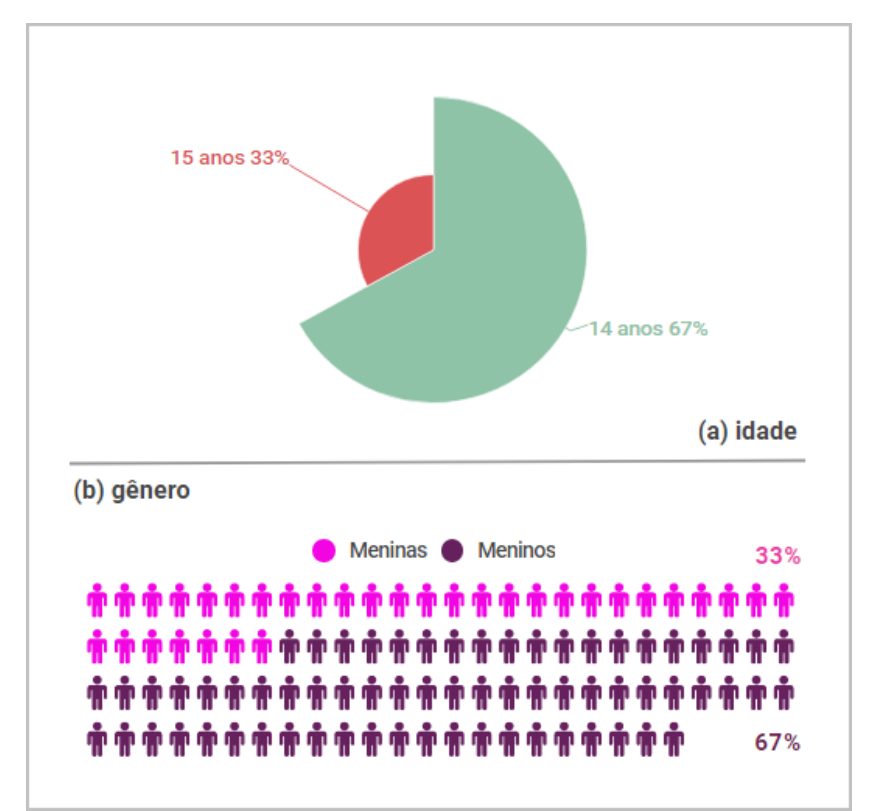

Figura 7 - Caracterização dos participantes: (a)Idade dos estudantes e (b) gênero. Fonte: Questionário aplicado no Colégio Tiradentes da Brigada Militar.

Após, questionou-se os estudantes sobre o uso de tecnologias e softwares (Figura 8). Observou-se que $88 \%$ dos alunos sempre ou quase sempre faz uso dessas ferramentas. Em especial, utilizam o Google Maps, Google, Facebook e outras Redes Sociais em geral, Word, Power Point, Photoshop, Calculadora, Tradutor, Jogos, E-mail, e WhatsApp. A finalidade desses usos perpassa pela comunicação, localização, pesquisas em geral, realização de trabalhos de um curso de informática e de trabalhos de aula, entretenimentos diversos e curiosidades. Assim, evidencia-se que há uma aproximação maior desses estudantes com as mídias, sobretudo no que tange a aplicativos que apresentam mapas híbridos e multimodais, o que pode aproximá-los da pesquisa realizada.

Com relação ao uso das/os ferramentas/softwares os alunos destacaram que as empregam "Em coisas do dia a dia desde pesquisas para trabalhos até para achar localizações para não me perder"; "Essas ferramentas ajudam no nosso cotidiano e facilitam o desenvolvimento de qualquer atividade"; "Eu uso principalmente para trabalho escolar, pois acho as informações facilmente em sites de pesquisa"; "Uso mais por curiosidade e diversão"; e "Facilita o nosso cotidiano como um todo em comunicação, em localização, etc. ". 


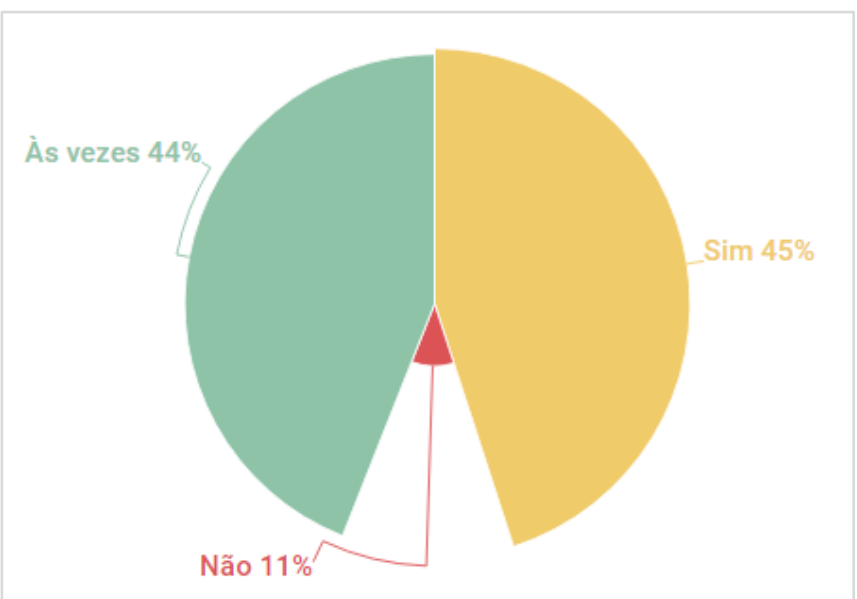

Figura 8 - Resposta a questão "Você costuma utilizar ferramentas/softwares tecnológicas/os no seu cotidiano?" Fonte: Questionário aplicado no Colégio Tiradentes da Brigada Militar.

Na sequência os alunos foram questionados se costumam observar a presença de mapas nessas ferramentas/softwares. Apenas $13 \%$ não observam como apresentado na Figura 9. Tal fato enriquece a leitura de mapas pelos estudantes, pois eles já fazem uso dessa (múltipla) linguagem em seu cotidiano sendo, portanto, mais familiarizados com a leitura, interpretação e mapeamento. Isso também foi ressaltado pelos alunos ao relatarem que outrora o Colégio ofertava a modalidade de Corrida de Orientação entre suas práticas, familiarizando os estudantes com os mapas e com a Cartografia.

Figura 9 - Resposta a questão "Costuma observar a presença de mapas nessas ferramentas/softwares?" Fonte: Questionário aplicado no Colégio Tiradentes da Brigada Militar.

Dos participantes da pesquisa, 62\% apontaram que observam alterações dos mapas analógicos para os mapas digitais e 38\% percebe algumas alterações. Contudo, nenhum estudante apontou não observar mudanças dos mapas tradicionais para os contemporâneos. Entre as mudanças eles destacaram: "Nos mapas digitais as informações são mais facilmente alteradas e atualizadas"; "Nos mapas digitais há maior possibilidade para modificações"; "A quantidade de informações 
'escondidas 5 " para serem utilizadas"; "A organização dos mapas digitais me parece melhor”; "Relevo, Formato, Utilidades e Divisão dos Países"; e "Praticidade e Precisão".

Destaca-se que todos responderam que isso afeta como você compreende o espaço em que está inserido e todos acreditam que os mapas híbridos e multimodais são ferramentas importantes para a sua compreensão do lugar onde vive, pois "Podemos ver onde os lugares tiveram mudanças"; "Pois se trata de uma visão específica e didática”; "Ajudam eu me situar e me localizar"; "São importantes, pois eu poderia compreender melhor o lugar onde vivo"; e "São mais práticos e simples".

Com relação com o ensino de Geografia os alunos pensam que é possível aprender mais por meio de mapas tecnológicos, porque "Sim, pois estamos interagindo com a tecnologia no dia a dia sendo assim é mais fácil aprender com elas"; "Elas nos permitem visualizar o lugar que vivemos com maior precisão"; "Os mapas tecnológicos são mais detalhado”; "Sim, pois nos permitem relacionar os conteúdos com mais facilidade e entender melhor as matérias"; "Sim, pois facilita o ensino e eu aprendo melhor sobre clima, relevo e a pensar..."; "Também! É impossível aprender Geografia sem o uso de mapas e os tecnológicos facilitam a aprendizagem"; e "Sim, por permitir manusear uma grande quantia de dados e pela facilidade de utilizar ferramentas para coletas de dados".

O perfil apresentado pelos alunos das duas Instituições de Ensino evidencia que as tecnologias se constituem em um facilitador do processo de ensino-aprendizagem de modo mais articulado, dinâmico, compartilhado como se espera dos alunos do século XXI, pois eles estão inseridos na realidade virtual e a utilizam para fins de aprendizagem. Além disso, pode-se inferir que, os mapas digitais e sua linguagem multimodal, estão integrados no uso cotidiano e no contexto vivido na sociedade atual, seja para localização, para deslocamento, para clima e tempo, relevo, distâncias. E, desta forma, a Cartografia Escolar pode ser protagonista da transformação metodológica necessária no ensino em geral e, especialmente, no ensino de Geografia.

Vive-se em um momento de grandes mudanças e a escola tem o papel de preparar o "novo" cidadão que emerge da liquidez da Modernidade. Cabe, principalmente, à escola encaminhar a "nova" sociedade emergente, no caminho da superação do instrucionismo e reprodutivismo para adentrar em uma perspectiva de construção de autonomia e de polimento da inteligência que permitem relacionar-se com o conhecimento de outro modo, seja novo ou constantemente atualizado.

No mundo de hoje, nosso aluno não pode apenas encontrar a informação, faz-se necessário à reflexão e o questionamento, para que reelabore esta informação e assim seja transformada em um saber apropriado para o enfrentamento das circunstâncias da vida cotidiana. Em seu livro "As Cinco

\footnotetext{
${ }^{5}$ Referência aos layers ou camadas de um mapa digital.
} 
Mentes para o Futuro", Gardner (2007) defende que uma delas está relacionada à capacidade de síntese e de organização do conhecimento. Diz respeito à habilidade de selecionar e definir o conhecimento que se constitui em estratégico a cada momento de sua vida. A escola pode auxiliar no desenvolvimento deste potencial do aluno por meio de atividades que o prepare para o "novo" mundo e, para isso, fazem-se pertinentes reflexões sobre a proposta metodológica desenvolvida e, em parte, aqui apresentada.

\section{REFLEXÕES SOBRE A PROPOSTA METODOLÓGICA}

Com relação à aplicação da proposta metodológica propriamente dita, destaca-se que foi pensada para o desenvolvimento coletivo e colaborativo das atividades, pois na contemporaneidade, ocorre a busca pela formação de indivíduos "muito bem preparados tecnicamente, capazes de reconhecer e exercer valores como: conduta ética, capacidade de iniciativa, criatividade, flexibilidade e autocontrole, comunicação, dentre outros” (BERNINI, 2017, p. 104). Assim, esse "novo" perfil propõe ao aluno "se envolver ativamente no processo de aprendizagem, sempre buscando a prática de ler, escrever, perguntar, discutir, resolver problemas e desenvolver projetos [...]. O estudante deve realizar tarefas mentais de alto nível, como análise, síntese e avaliação" (BERNINI, 2017, p. 105).

Por isso, emerge a necessidade de se pensar metodologias pautadas na aprendizagem colaborativa, que podem ser definidas "como atividades que levam o aluno a pensar, constantemente, sobre o que está fazendo, com acesso a diferentes fontes de informações que poderão auxiliá-lo na tarefa" (BERNINI, 2017, p. 105). Neste sentido, as tarefas pensadas para a presente proposta metodológica pautada nos multiletramentos na Cartografia Escolar envolveram a realização de: (1) práticas situadas na medida em que promove a experimentação sobre a realidade conhecida por meio de softwares novos para o contexto dos estudantes; (2) prática transformada discutindo conceitos cartográficos e geográficos e suas aplicações para a produção de mapas e do site; (3) instrução aberta por meio das conceitualizações necessárias às práticas pedagógicas; e (4) enquadramento crítico na medida em que realiza a análise da crítica do espaço geográfico, caracterizando o município de Santa Maria, RS, e funcional do mapa enquanto recurso híbrido e multimodal (COPE; KALANTZIS, 2009).

Os Quadros 1 e 2 apresentam o cronograma desenvolvido nas duas Instituições de Ensino e a estruturação da proposta metodológica no espaço escolar. Na EMEF Junto ao CAIC Luizinho de Grandi as atividades foram desenvolvidas com duas turmas de Ensino Fundamental: um sétimo e 
um oitavo $\operatorname{anos}^{6}$, nos dois últimos períodos de Geografia, de 55 minutos cada, das quintas-feiras dos meses de outubro, novembro e dezembro de 2018. Assim, organizaram-se as atividades conforme o cronograma a seguir (Quadro 1). Ressalta-se que algumas etapas foram compartilhadas entre as duas turmas e outras foram exclusivas de cada turma.

Quadro 1 - Cronograma de aplicação da proposta metodológica para a Cartografia Escolar no ensino de Geografia realizada na EMEF Junto ao CAIC Luizinho de Grandi, em 2018.

\section{$7^{\circ}$ AMARELO}

ATIVIDADE DESENVOLVIDA

Termo de Consentimento Livre e Esclarecido e Termo de Assentimento

Entrega até 30
de setembro

Aula 1

Apresentação do projeto, dos procedimentos metodológicos e dos conceitos-chave para o entendimento da proposta metodológica

Aula 2 Mapa de Localização de Santa Maria

Aula 3 Mapa da Divisão dos Bairros de Santa Maria

Aula 4

Aula 5

Aula 6

Aula 7

Aula 8

Aula 9 e 10
Mapas de Características da População Trabalho com o aplicativo Windy para compreensão da Dinâmica Climática no Hemisfério Sul e, por conseguinte, em Santa Maria Mapa da Hidrografia de Santa Maria Mapa do Relevo e da Hidrografia de Santa Maria Finalização da arte final dos mapas (análise dos mapas impressos e ajustes) e trabalho sobre organização e designe de site.

\section{Mapa de Localização da EMEF Junto ao CAIC} Luizinho de Grandi

Mapa da Divisão das Regiões Administrativas de

Santa Maria
Mapas de Características da População

Mapas de Características da População

Aula 11

Aula 12

Organização colaborativa do site https://tesecartoescolar20.wixsite.com/metodologia, aba pelos olhos do CAIC

Questionário final e avaliação da metodologia Confraternização entre as turmas envolvidas na proposta**

*Atividade executada na terça-feira por ser realizada na sala multimídia. **Atividade executada na terça-feira por ser realizada no Refeitório.

Fonte: Organização dos Autores, 2018.

A Figura 10 apresenta alguns momentos da aplicação da atividade com os estudantes das duas turmas na EMEF Junto ao CAIC Luizinho de Grandi e a Figura 11 demostra exemplos de mapas confeccionados pelos estudantes durantes as aulas de Geografia.

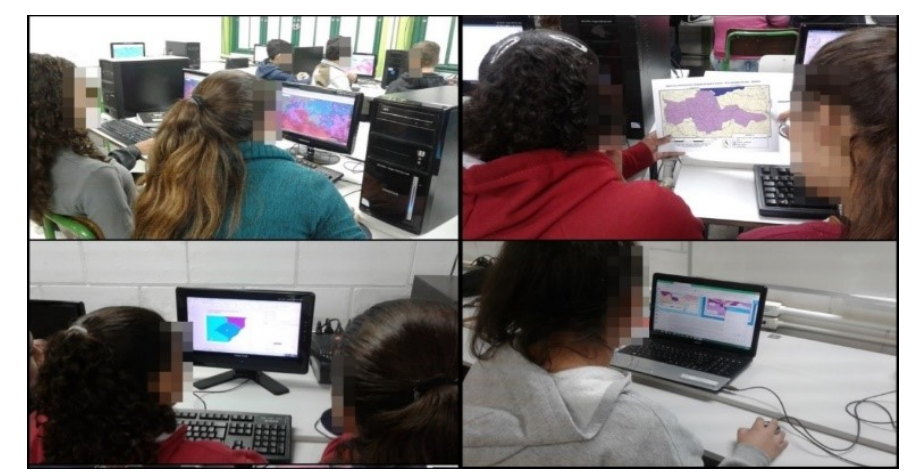

Figura 10 - Prática na EMEF Junto ao CAIC Luizinho de Grandi.

Fonte: Atividade na EMEF Junto ao CAIC Luizinho de Grandi.

\footnotetext{
${ }^{6} \mathrm{Na}$ EMEF Junto ao CAIC Luizinho de Grandi são atribuídas cores as turmas para evitar que se tenha uma ideia de ranqueamento das turmas dos estudantes como numeração e ordem alfabética, normalmente, remetem. Assim, as cores funcionam como elemento de identificação dos grupos e não como ordenamento das turmas.
} 


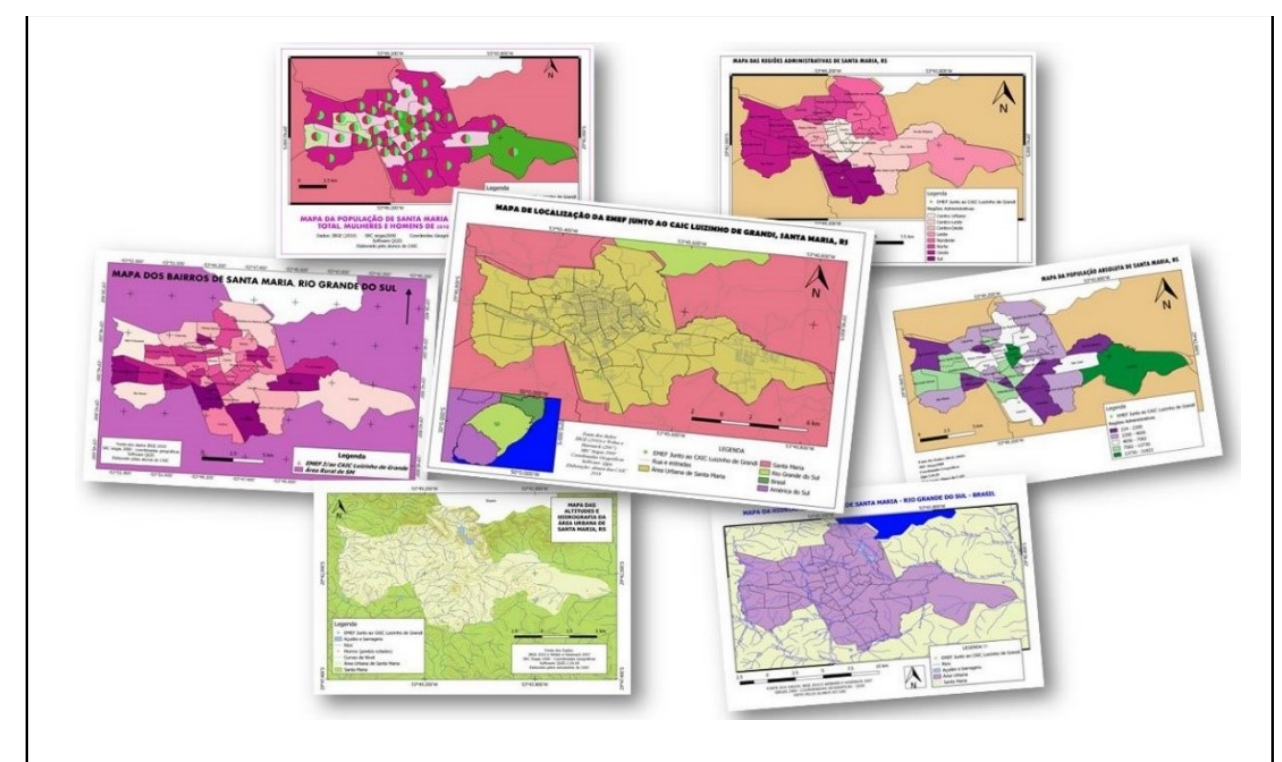

Figura 11 - Exemplos de mapas produzidos na EMEF Junto ao CAIC Luizinho de Grandi ${ }^{7}$. Fonte: Produção dos alunos da EMEF Junto ao CAIC Luizinho de Grandi.

No Colégio Tiradentes da Brigada Militar as atividades foram desenvolvidas com alunos voluntários que se dispuseram participar das Oficinas em turno inverso. O Colégio não possui laboratório de informática, então, os próprios estudantes e pesquisadores levavam seus notebooks para a realização das atividades pedagógicas. Inicialmente, o cronograma previa a divisão do grupo em duas equipes que se revezariam na construção dos produtos multimodais. Entretanto, os estudantes manifestaram interesse em participar de todas as etapas do projeto, trabalhando-se, então, com apenas uma equipe. Todos os estudantes envolvidos nas atividades estavam matriculados no $1^{\circ}$ ano do Ensino Médio e possuem Termo de Consentimento Livre e Esclarecido (TCLE) e Termo de Assentimento (TA) assinado pelos alunos e pelos seus responsáveis. Todas as Oficinas foram realizadas entre Outubro e Dezembro, nas quartas e sextas-feiras à tarde, com duração de aproximadamente 3 horas e 30 minutos. Assim, organizaram-se as atividades conforme o cronograma do Quadro 2.

\footnotetext{
${ }^{7}$ Para visualizá-los em resolução máxima acesse: https://tesecartoescolar20.wixsite.com/metodologia.
} 
Quadro 2 - Cronograma de aplicação da proposta metodológica para a Cartografia Escolar no ensino de Geografia realizada no Colégio Tiradentes da Brigada Militar, em 2018.

Entrega até 30 de setembro

Oficina 1

Oficina 2

Oficina 3

Oficina 4

Oficina 5

Oficina 6

\section{ATIVIDADE DESENVOLVIDA}

\section{Termo de Consentimento Livre e Esclarecido e Termo de Assentimento}

Apresentação do projeto, dos procedimentos metodológicos e dos conceitos-chave para o entendimento da proposta metodológica.

Trabalho com o aplicativo Windy para compreensão da Dinâmica Climática no Hemisfério Sul e, por conseguinte, em Santa Maria.

Atividades sobre o relevo de Santa Maria utilizando o Google Earth e imagens anaglifo. Mapa de Localização de Santa Maria, Mapa de Localização do Colégio Tiradentes da Brigada Militar.

Mapa da Divisão dos Bairros de Santa Maria, Mapa das Regiões Administrativas de Santa Maria e Mapa de Características Populacionais de Santa Maria.

Mapa de Características Populacionais de Santa Maria, Mapa de Hidrografia e Relevo. Finalização da arte final dos mapas (análise dos mapas impressos e ajustes) e trabalho sobre organização e designe de site.

Organização colaborativa do site https://tesecartoescolar20.wixsite.com/metodologia, aba pelos olhos do CTBM

Questionário final e avaliação da metodologia

Confraternização entre os envolvidos na proposta

Fonte: Organização dos Autores, 2018.

A Figura 12 apresenta alguns momentos da aplicação da atividade com os estudantes do Colégio Tiradentes da Brigada Militar e a Figura 13 demostra exemplos de mapas confeccionados durante as Oficinas Pedagógicas.

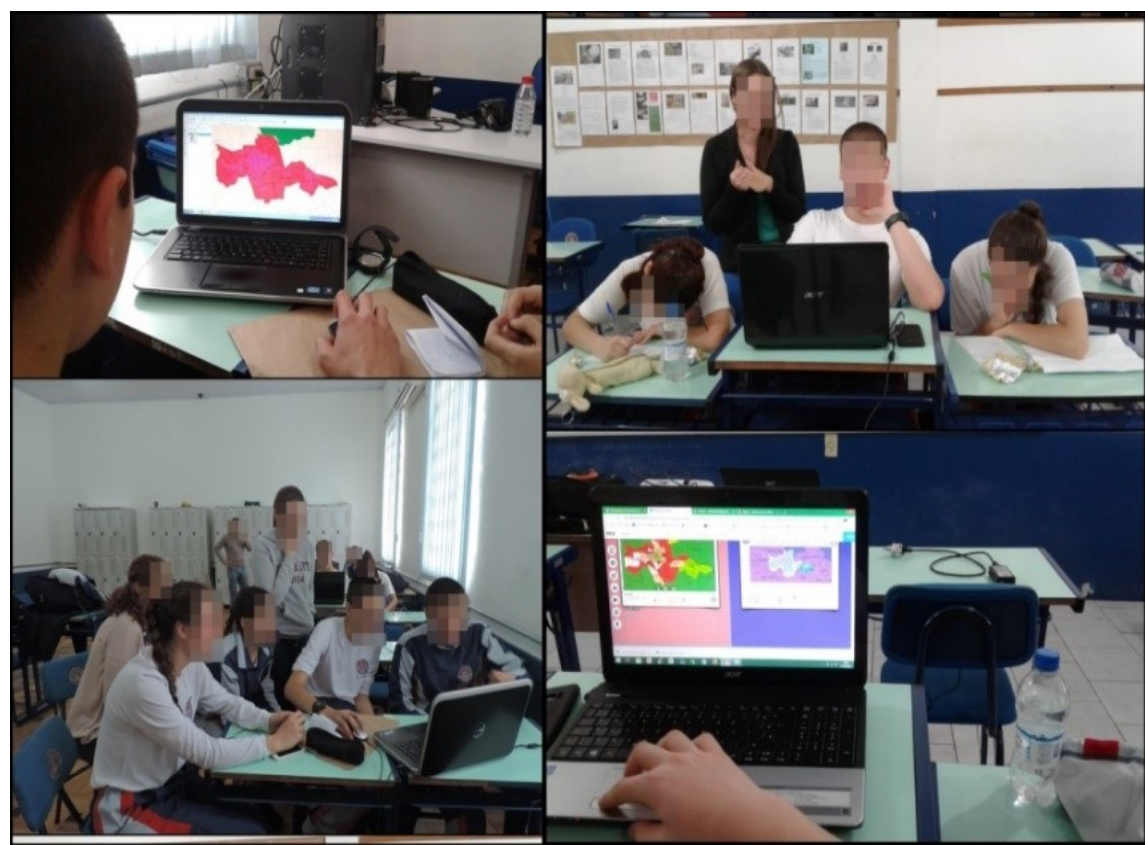

Figura 12 - Prática no Colégio Tiradentes da Brigada Militar.

Fonte: Atividade no Colégio Tiradentes da Brigada Militar.

As oficinas visaram trabalhar com o entendimento do processo de mapeamento e de leitura e interpretação de mapas. Enfocaram a utilização do QGIS como um Sistema de Informação 
Geográfica capaz de auxiliar a espacialização de diferentes temáticas, bem como que potencializa o trabalho com diferentes bancos de dados geográficos. O software é livre, ou seja, gratuito e possui compatibilidade com inúmeros sistemas computacionais e isso facilitou a interação dos estudantes com ele. Tanto na instalação nos próprios notebooks como na instalação no laboratório de informática (com Linux), os estudantes tiveram acesso a todas as ferramentas que necessitaram para a realização dos seus mapeamentos e puderam explorar detalhadamente os plug-ins, geralmente, utilizados para cada tipo de mapa. Todos se motivaram e aprofundaram a discussão sobre o design dos mapas, especialmente, no compositor de impressão do QGIS e brincaram com as combinações de cores e possibilidades interativas que o software lhes permite realizar no emprego da estruturação de seus mapas.

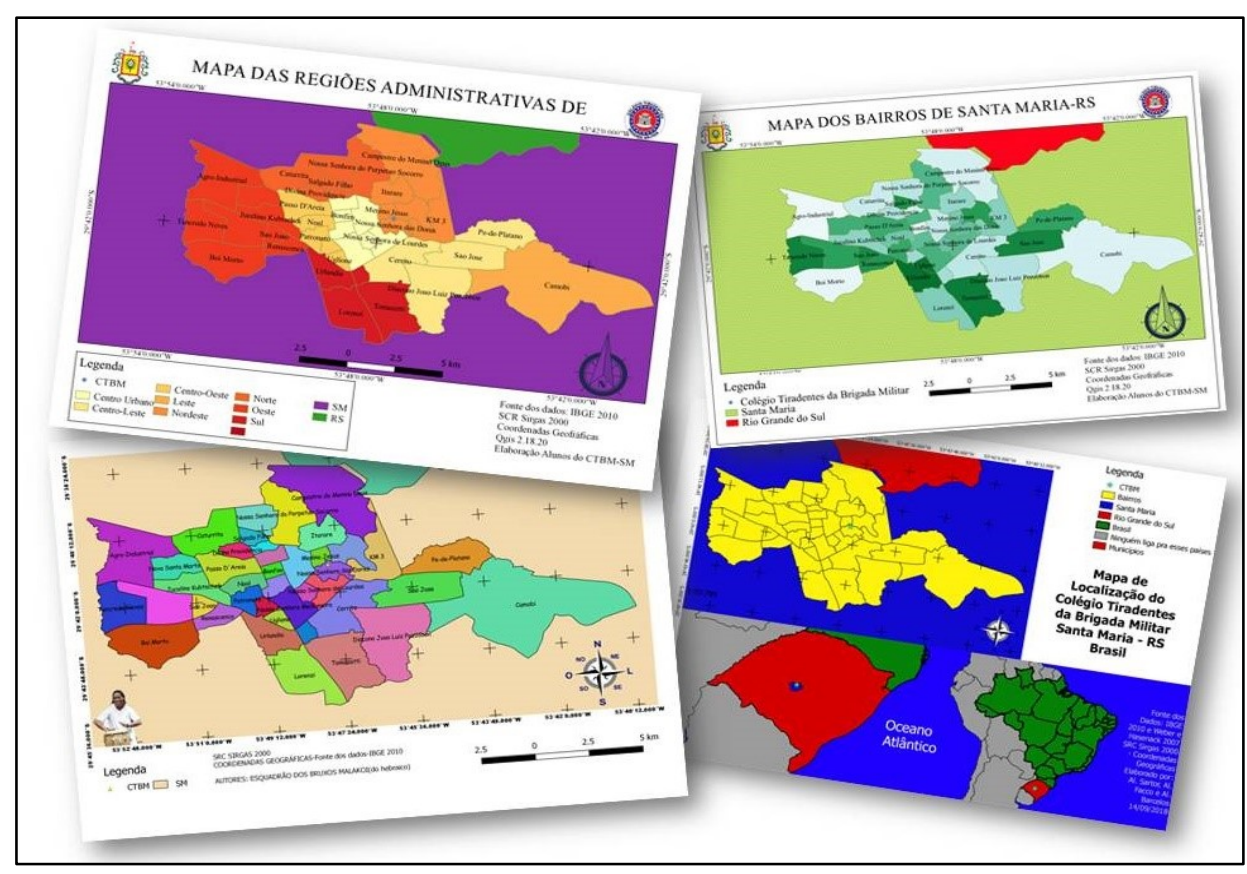

Figura 13 - Exemplos de mapas produzidos no Colégio Tiradentes da Brigada Militar ${ }^{8}$. Fonte: Produção dos alunos do Colégio Tiradentes da Brigada Militar.

Nas atividades com o Google Earth, priorizou-se a observação do relevo em três dimensões e a elaboração de perfis topográficos da área urbana de Santa Maria/RS. Essa visualização por meio do globo digital foi comparada com as curvas de nível e pontos cotados nos mapeamentos realizados pelos estudantes com o QGIS, facilitando o seu entendimento sobre o tema em questão. Além disso, eles visualizaram imagens anaglifo da cidade levadas pela pesquisadora como forma de reforçar o entendimento da representação do relevo em curvas de nível e tridimensionalmente. Os estudantes também reproduziram passeios sobre esses trajetos inseridos visualizando o relevo como se o sobrevoassem. Tal atividade despertou suas curiosidades e o desejo de "viajar" por outros lugares do globo terrestre como os diversos estádios de futebol, pontos

\footnotetext{
${ }^{8}$ Para visualizá-los em resolução máxima acesse: https://tesecartoescolar20.wixsite.com/metodologia.
} 
turísticos mundiais e o município de Chapecó/SC. Realizaram cálculos de distância por meio a inserção de caminhos e cálculos de área com a inserção de polígonos, bem como identificaram coordenadas pela inserção de pontos. Após todas essas etapas, ainda realizou-se a localização de Santa Maria/RS no contexto global por meio da visualização do globo digital como um todo, a fim de auxiliá-los na elaboração das explicações sobre os mapas de localização e de contribuir para a alfabetização e letramento cartográfico por meio de práticas multiletradas e mapas híbridos e multimodais.

No Windy, em associação com os mapas do QGIS e com a prática no Google Earth, os estudantes observaram as zonas climáticas mundiais e diversos elementos (umidade, pressão e temperatura) e fatores do clima (altitude, latitude, continentalidade, maritimidade, relevo, vegetação, massas de ar e urbanização), buscando caracterizar os tipos de tempo em Santa Maria/RS. No dia da realização da atividade, a projeção dinâmica da previsão do tempo demostrava o avanço de uma frente fria sobre o Rio Grande do Sul e isso tornou ainda mais rica a discussão sobre as condições de tempo em Santa Maria, pois os alunos observaram a previsão, descreveram o avanço da frente fria e vivenciaram a sua chegada e efeitos no cotidiano, permitindo uma construção significativa do entendimento do processo descrito.

Depois de todas as Oficinas e aulas desenvolvidas nas duas Instituições de Ensino a pesquisadora organizou a base de um site no WixSite ${ }^{9}$ (Figura 14). O recurso multimodal visou integrar as produções da EMEF Junto ao CAIC Luizinho de Grandi e do Colégio Tiradentes da Brigada Militar. Para isso, foi composto por uma tela de apresentação do projeto, outra para contato e outras para desenvolvimento de cada grupo de alunos das Instituições de Ensino denominadas: "Pelos Olhos do CAIC" e "Pelos olhos do CTBM". Os alunos, então, organizaram as suas interfaces como preferiram: estipularam a interface gráfica, selecionaram os mapas e demais informações a serem divulgadas, escolheram cores, letras e tamanhos para todos os elementos que integraram o material, resultando em um site compartilhado entre todos os estudantes participantes da pesquisa. Isso estimulou a colaboração e a cooperação e potencializou a interação entre alunos que não se conhecem pessoalmente, mas que produziram em conjunto uma (re)leitura do espaço urbano de Santa Maria/RS.

O processo de criação do site de forma colaborativa estimulou o trabalho compartilhado e o respeito às diferenças de pensamentos entre os estudantes, visando colaborar com a aproximação dos seus gostos e interesses com os conteúdos de Geografia e da Cartografia Escolar. Assim, o site serviu como um repositório das principais atividades do projeto e, mais do que isso, como um exercício de sistematização do conhecimento construído pelos estudantes e de divulgação se saberes geográficos, cartográficos e do local de estudo. O material despertou forte sentimento de

${ }^{9}$ Disponível em: https://tesecartoescolar20.wixsite.com/metodologia, acesso em janeiro de 2019. 
pertencimento nos alunos que se referiam ao projeto como "o trabalho dos nossos mapas e nosso site".

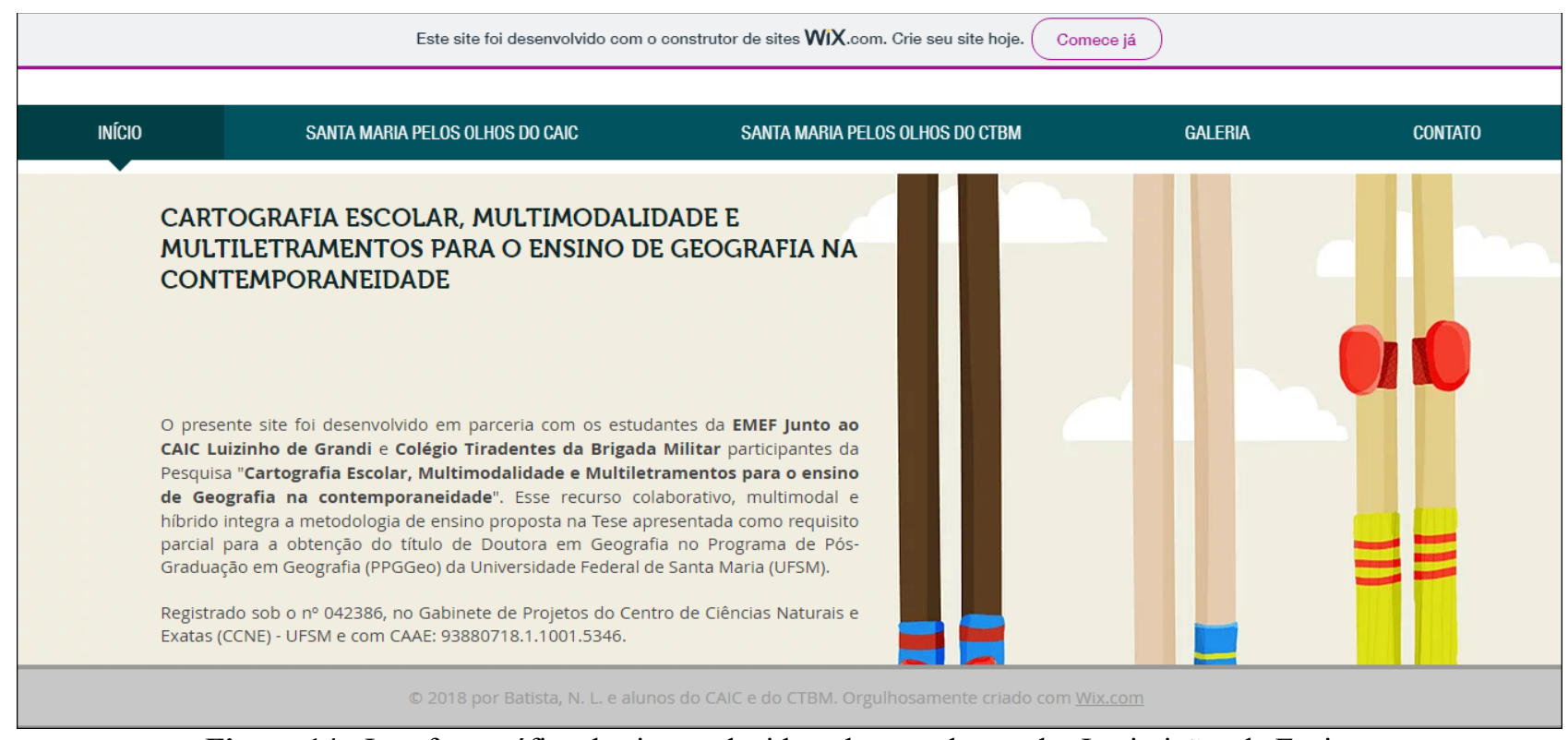

Figura 14 - Interface gráfica do site produzido pelos estudantes das Instituições de Ensino.

Fonte: produção coletiva entre Autores e alunos das duas Instituições de Ensino, 2018.

Os mapas no site permitiram, também, a integração cidadã com os moradores dos bairros e a população do município e de qualquer espaço do Brasil e do mundo, mostrando, também, a leitura democrática e interativa que os mapas e as tecnologias proporcionam na atualidade. $\mathrm{O}$ site como recurso multimodal permite a interação entre os estudantes das duas Instituições de Ensino, com a comunidade e com o público em geral que se interesse em acessar e conhecer o trabalho realizado pelos estudantes. O material foi detalhadamente pensado por cada grupo, prezando pela interatividade e pela utilização de imagens como fonte de informação. A confecção do site permitiu conceber o design do produto multimodal, criar inter-relações entre os conceitos trabalhados, estimulou a imaginação, possibilitou inventar formas dos alunos construírem o seu próprio conhecimento e idealizar o espaço local como os estudantes o vem e o desejam.

Observou-se grande envolvimento dos estudantes em todas as etapas da proposta, pois a mesma estimulou o uso de práticas situadas, na medida em que promoveu a experimentação, sobre a realidade conhecida por meio de softwares novos para o contexto dos estudantes; prática transformada discutindo conceitos cartográficos e geográficos e suas aplicações para a produção de mapas e do site; instrução aberta por meio das conceitualizações necessárias às práticas pedagógicas; e enquadramento crítico na medida em que realiza a análise da crítica do espaço geográfico, caracterizando a área urbana de Santa Maria, RS, e funcional do mapa enquanto recurso híbrido e multimodal. Isso resultou em uma proposta multiletrada que estimulou a cidadania ao proporcionar uma reflexão sobre a área urbana do município de Santa Maria/RS e a aprendizagem 
colaborativa reforçando o quanto é mecessário pensar essas interfaces no ensino de Geografia e na Cartografia Escolar.

\section{SOBRE A AVALIAÇÃO DA PROPOSTA METODOLÓGICA}

Para a avaliação da proposta aplicou-se outro questionário semiestruturado questionando a interação dos alunos com a proposta e como eles compreenderam e se sentiram no decorrer da metodologia. Os resultados foram apresentados na sequência.

Inicialmente, questionou-se se os estudantes pensam que as propostas apresentadas ao longo da sequência didática colaboraram com sua aprendizagem em relação aos mapas híbridos $e$ multimodais. Em ambas as Instituições de Ensino a grande maioria foi enfática ao apontar que sim, isto é, que colaboraram com a aprendizagem. Na EMEF CAIC Luizinho de Grandi, 89\% dos alunos pensam que os auxiliou na sua aprendizagem e 7\% que auxiliou em parte, como demostra o gráfico da Figura 15. Já no Colégio Tiradentes da Brigada Militar, 100\% pensa que as propostas apresentadas ao longo da sequência didática colaboraram com sua aprendizagem em relação aos mapas híbridos e multimodais.

Figura 15 - Resposta a questão "Você pensa que as propostas apresentadas ao longo da sequência didática colaboraram com sua aprendizagem em relação aos mapas híbridos e multimodais?"

Fonte: Questionário na EMEF Junto ao CAIC Luizinho de Grandi.

No Quadro 3, apresentaram-se as justificativas apontadas pelos estudantes sobre o porquê a proposta os auxiliou ou não no processo de ensino e aprendizagem sobre o tema desenvolvido. Observa-se que os estudantes apresentam temáticas relacionadas ao aprendizado de coisas novas de modo divertido e interativo, despertando o desejo de aprender mais e a familiarização com os softwares que eram desconhecidos da grande maioria até o momento da aplicação. Além disso, é ressaltado que o fato de construir os próprios mapas colabora com o desenvolvimento de habilidades e competências voltadas a metodologia apresentada por Simielli (1999) que aponta que 
os alunos devem ser leitores críticos e mapeadores conscientes, assim como colabora com o estímulo à edificação do pensamento espacial e do raciocínio geográficos defendidos pela BNCC.

Além dos relatos, organizou-se uma questão fechada para que os estudantes marcassem a sua opinião, buscando identificar potencialidades e fragilidades da metodologia. Em ambas as Instituições de Ensino predominaram opiniões que expressam que a proposta foi dinâmica e interativa e que permitiram criar um caminho para a própria aprendizagem, conforme demostra a Figura 16. No item "outras” os alunos da EMEF Junto ao CAIC Luizinho de Grandi mencionaram que foram "interessante e eu queria participar mais", "achei muito legal tudo", "interessante e divertido", ou que pensou ser "longa e cansativa". Já no Colégio Tiradentes da Brigada Militar destacaram que "envolveu os alunos do $1^{\circ}$ ano em prol de um mesmo objetivo: conhecimento, companheirismo e cartografia", "colaboraram extremamente para ampliar a minha bagagem de conhecimentos" e "no início o software era complicado de manusear, mas era só questão de prática e paciência”.

Quadro 3 - Justificativas apontadas pelos estudantes sobre o porquê as atividades apresentadas ao longo da sequência didática colaboraram com sua aprendizagem em relação aos mapas híbridos e multimodais

\section{CONTRIBUIÇÕES NA EMEF JUNTO AO CAIC CONTRIBUIÇÕES NO COLÉGIO TIRADENTES LUIZINHO DE GRANDI DA BRIGADA MILITAR}

1. Eles nos ajudam saber mais sobre onde estamos e onde podemos ir;

2. Porque você aprende coisas novas;

3. Porque quando experimentamos coisas novas e divertidas é mais fácil aprender;

4. Eu não entendo muito do assunto, mas pude aprender mais;

5. Porque nos mesmos fazendo o mapa torna mais fácil entendermos do que se os outros fizessem por nós;

6. Porque aprendemos nos localizar e também finalizar mapas;

7. As explicações ajudam a entender melhor;

8. Porque é uma forma divertida de aprender;

9. Ajudou a conhecer melhor os mapas quando alguém te pergunta você sabe explicar o que é;
1. Com o passar dos encontros aprendi muito sobre o estudo e compreensão dos mapas. Aprendi a interpretar, fazer e conhecer novos métodos de aprendizagem voltados à localização, as áreas rurais e urbanas e aos habitantes dessas áreas;

2. Estou mais familiarizado com esse tipo de programa;

3. Meu entendimento sobre os mapas melhorou;

4. Com a experiência ganha é mais fácil entender os mapas;

5. Porque foi interessante aprender coisas novas;

6. Conheci novas técnicas e estudei novos lugares;

7. Porque são conhecimentos que ficam gravados e que poderão ser utilizados para o desenvolvimento de trabalhos;

8. Pois aprendemos a montá-los e também entendemos como lê-los mais facilmente;

9. O aprimoramento do conhecimento é sem dúvida sempre um bônus que possibilita ampliar os nossos conhecimentos, possuía pouco conhecimento do tema e agora aprendi bem mais.

Fonte: Questionário aplicado aos estudantes participantes da pesquisa, nas duas Instituições de Ensino, 2018.

As potencialidades e fragilidades da proposta metodológica foram apresentadas no Quadro 4. Quanto às potencialidades apontadas pelos alunos, demostram-se vários momentos específicos da aplicação da proposta, mostrando que de acordo com as habilidades de cada estudante, eles se identificaram mais ou menos com cada etapa. Já as fragilidades remontam a própria interação com o software e dificuldades comuns aos primeiros usos dos Sistemas de Informação Geográfica por 
qualquer estudante em qualquer nível. Observou-se também o destaque a dificuldade de escrever, o que pode estar associada ao não hábito de leituras e uso de mídias apenas para fins de diversão e não para estudo como muitos alunos destacam na caracterização das turmas.

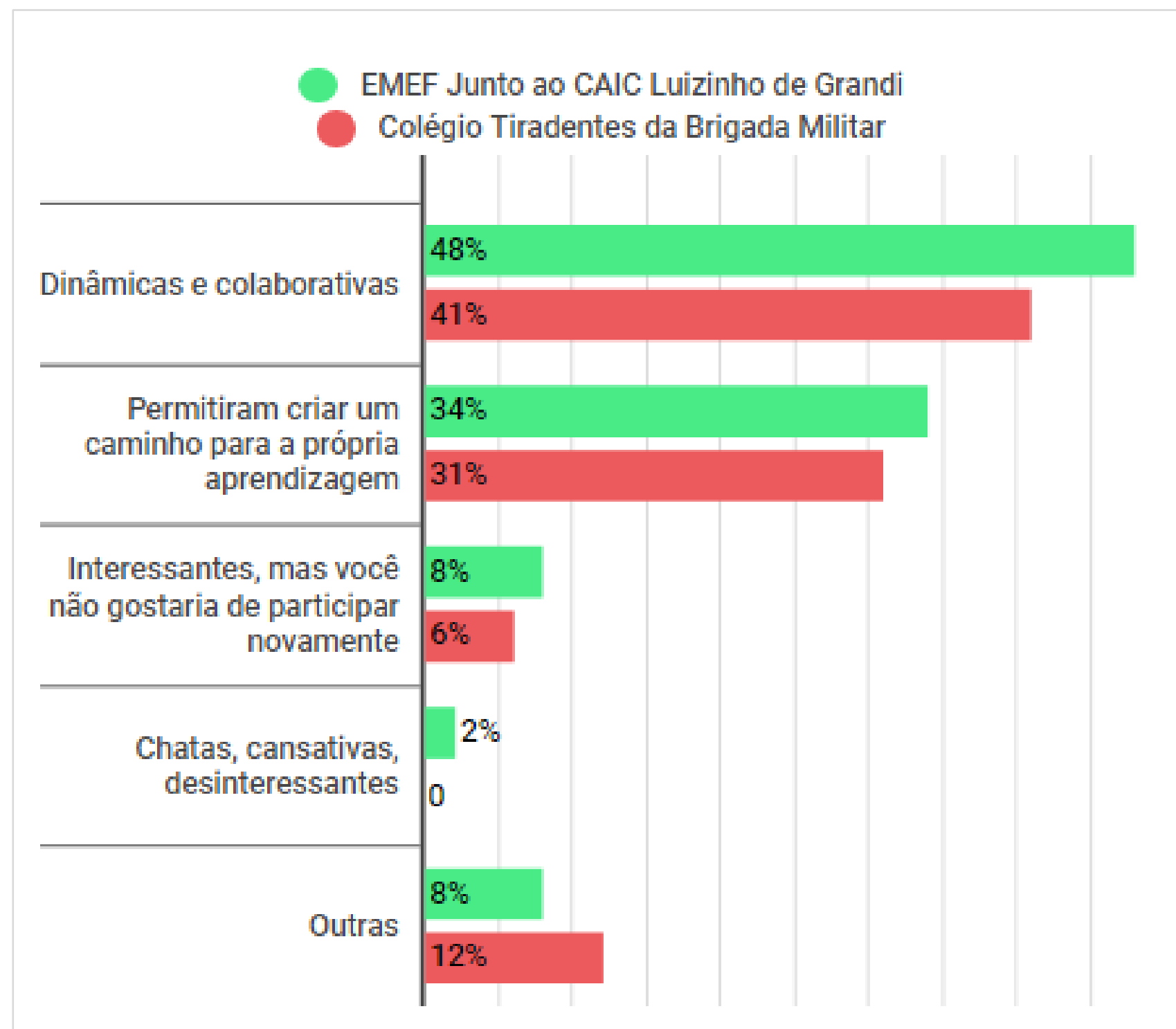

Figura 16 - Resposta a questão "Em sua opinião, as propostas foram..." - (a) EMEF Junto ao CAIC Luizinho de Grandi e (b) Colégio Tiradentes da Brigada Militar.

Fonte: Questionário aplicado nas duas Instituições de Ensino, 2018.

Na EMEF Junto ao CAIC Luizinho de Grandi há unanimidade quanto ao desejo de continuar realizando atividades voltadas ao projeto e aos mapeamentos com softwares livres em âmbito das aulas de Geografia. Já no Colégio Tiradentes da Brigada Militar observou-se o desejo de que a proposta passasse a ter maior duração e fosse ampliada para as demais turmas da Instituição. Outro fato relevante neste Colégio é o gosto pela realização de competições, que é muito adotada em práticas extraclasse, e que estimula os alunos a se dedicaram as propostas o que remete a 
gamificação de persuasão e pode vir a ser uma proposta interessante em determinados contextos e desenvolvimentos de atividades na Educação Básica.

Quadro 4 - Potencialidades e Fragilidades da Proposta desenvolvida

\section{POTENCIALIDADES NA EMEF JUNTO AO CAIC LUIZINHO DE GRANDI \\ POTENCIALIDADES NO COLÉGIO TIRADENTES DA BRIGADA MILITAR}

1. Foi tudo muito bom, legal, divertido e interessante;

2. Novas formas de aprendizagem colaborativa entre os alunos;

3. Coisa bacana foi que não tivemos teste e depois que peguei o jeito do programa eu gostei;

4. Todo mundo trabalhou bem e eu não vi brigas;

5. Fomos à sala de informática, aprendemos fazer mapas e usamos o Windy;

6. Acho legal mexer no computador e fazer mapas. Nós não precisamos ficar só na sala de aula;

7. Nos ensinou a interpretar melhor os mapas e aprendemos mexer melhor no computador;

8. Aprender a fazer mapas e ter aulas mais interativas;

9. Foi legal porque deu para conhecer melhor Santa Maria;

10. Eu gostei de ir para o laboratório de informática, de escrever textos e de saber mais sobre os mapas;

11. Amei colorir os mapas e fazer as legendas;

12. Gostei porque todos interagiram, foi bem legal;

13. Nós podemos aprender criando e lendo, e criamos o nosso próprio site.
1. Integração de alunos das diferentes turmas;

2. Responsabilidade, coleguismo e companheirismo;

3. Facilidade no entendimento, interação em grupo, explicação clara da professora e companheirismo;

4. Desenvolvimento de mapas de utilidade pública, ensinamentos práticos para os estudantes, formando uma base de cartografia para os futuros profissionais, incentivo aos participantes para o melhor entendimento dos mapas cartográficos;

5. Utilização de um programa até então desconhecido, configurar e personalizar mapas e criar legendas expondo o que o mapa mostra;

6. Conhecer melhor os lugares e utilizar tecnologias;

7. Desenvolvimento dos mapas ao longo do projeto trabalhou com diversos lugares, descobrimento de novos aplicativos e softwares;

8. Explorar a nossa capacidade de persistir no desenvolvimento de mapas sem sentir vontade de quebrar o PC, pode ajudar muito no futuro assim como a ter um pouco mais de noção do mundo em que vivemos; superou muitos as expectativas;

9. A possibilidade de desenvolver mapas de qualquer região;

10. Aprender sobre um tema pouco divulgado, ampliar horizontes tecnológicos interagir com o grupo.
FRAGILIDADES NA EMEF JUNTO AO CAIC LUIZINHO DE GRANDI

1. Tivemos que escrever textos muito grandes;

2. Os mapas têm muitos detalhes e são demorados para fazer;

3. A gente teve que fazer muitas coisas;
FRAGILIDADES NO COLÉGIO TIRADENTES DA BRIGADA MILITAR

1. Eu me esqueci de salvar o mapas e tive que refazer;

2. Foi um pouco cansativo, às vezes, mas devido ao processamento lento do notebook, outro motivo foi eu não poder ter ido a todos os encontros;

3. Não tenho nada que reclamar;

4. Algumas partes do QGIS eram um pouco complicadas;

5. Seria melhor ter começado no primeiro trimestre, assim teríamos mais encontros e não teria tantos feriados no dia do projeto.

6. Eu faltei em alguns encontros, pois a nossa rotina atrapalha um pouco;

Fonte: Questionário aplicado aos estudantes participantes da pesquisa, nas duas Instituições de Ensino, 2018. 
As sugestões apontadas no Quadro 6 remetem ao que os alunos entendem que poderia ser modificado no processo de desenvolvimento da proposta.

Quadro 6 - Sugestões e apontamentos realizados pelos alunos sobre a proposta desenvolvida nas duas Instituições de Ensino.

SUGESTÕES NA EMEF JUNTO AO CAIC LUIZINHO DE GRANDI
SUGESTÕES NO COLÉGIO TIRADENTES DA BRIGADA MILITAR

1. No próximo ano poderíamos fazer algo 1. Sugiro ter uma pausa para um lanche coletivo, parecido de novo;

2. Acho que deveria ter mais aulas assim;

3. Em todas as aulas poderia ter lanche coletivo;

4. Foi divertido e legal, poderíamos continuar tendo atividades assim;

5. Poderia ter mais trabalhos com mapas;

6. Poderíamos fazer mapas de outras regiões para ver como é. gradeço a oportunidade e carinho durante os encontros e principalmente pelo conhecimento compartilhado.

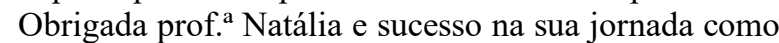
professora.

2. Que esse projeto se amplie para mais escolas. Beijos e muito obrigado!

3. Além de todos os conhecimentos sobre a construção de mapas poderia dar nota em Geografia.

4. Poderia ter algo de competitividade para incentivar ainda mais os estudantes;

5. O projeto poderia ser proposto também para os $2^{\circ}$ e $3^{\circ}$ anos, pois vi gente que também estava interessada em participar.

Fonte: Questionário aplicado aos estudantes participantes da pesquisa, nas duas Instituições de Ensino, 2018.

\section{CONCLUSÕES}

Com base no exposto ao longo do texto, observa-se que pensar metodologias de ensino de Cartografia Escolar para o ensino de Geografia, pautadas nas concepções de multiletramentos e multimodalidade e baseadas em softwares livres pode se tornar uma forma inovadora e eficiente de estimular o processo de ensino e de aprendizagem entre os estudantes da Educação Básica, pois se associa aos seus focos de interesse e motiva-os a estudarem e a compreenderem temas inerentes a Geografia. Esse formato de atividades, testado em sala de aula e em turno inverso, dinamiza as aulas e as tornam mais coerentes com o que se espera do professor do século XXI. Um professor conectado a novas metodologias e tecnologias, capaz de entender os objetivos e gostos de seus alunos e potencializar a sua aprendizagem a partir de ferramentas colaborativas e interativas.

Além disso, o trabalho com a área urbana do município de Santa Maria/RS contribui para colaborar com o conhecimento do espaço vivido, da realidade local e com o desenvolvimento das noções de identidade e cidadania por meio do pensamento espacial e do raciocínio geográfico como pondera a BNCC. Segundo o documento, "Essa é a grande contribuição da Geografia aos alunos da Educação Básica: desenvolver o pensamento espacial, estimulando o raciocínio geográfico para representar e interpretar o mundo em permanente transformação e relacionando componentes da sociedade e da natureza" (BRASIL, 2018, p. 358). Assim, a proposta metodológica apresentada e testada na EMEF Junto ao CAIC Luizinho de Grandi e no Colégio Tiradentes da Brigada Militar articulou os conhecimentos de Cartografia Escolar, as novas e múltiplas linguagens (por meio dos 
softwares livres e abarcando os preceitos da multimodalidade no ensino contemporâneo) e o ensino de Geografia se mostrando eficiente nos contextos de aplicação e colaborando com a aprendizagem dos estudantes de forma interativa e colaborativa no Ensino Fundamental e no Ensino Médio da Educação Básica.

\section{REFERÊNCIAS}

BATISTA, N. L. Cartografia Escolar, Multimodalidade e Multiletramentos para o ensino de Geografia na Contemporaneidade. 2019. 181 f. Tese (Doutorado em Geografia) - Programa de Pós-Graduação em Geografia, Universidade Federal de Santa Maria, Santa Maria, 2019.

BATISTA, N. L.; FELTRIN, T.; BECKER, E. L. S. Uma análise das práticas multiletradas de alunos do Ensino Fundamental em uma escola pública de Santa Maria/RS. Research, Society and Development, v. 8, n. 8, p. 1-16, 2019.

BATISTA, N. L.; BECKER, E. L. S.; CASSOL, R. Mapas híbridos e multimodais: em busca de multiletramentos na Cartografia Escolar. Pesquisar - Revista de Estudos e Pesquisas em Ensino de Geografia, Florianópolis, v. 5, n. 1, p. 19-35, 2018.

BERNINI, D. S. D. Uso das TICs como ferramenta na prática com metodologias ativas. In: DIAS, S. R; VOLPATO, A. N. Práticas inovadoras em metodologias ativas. Florianópolis: Contexto, 2017. cap. 6, p. 102-118.

BRASIL. Ministério da Educação. Base Nacional Comum Curricular - Ensino Fundamental. Brasília, 2018.

BRASIL. Ministério da Educação. Base Nacional Comum Curricular - Ensino Médio. Brasília, 2018b.

COPE, B.; KALANTZIS, M. Multiliteracies: New Literacies, New Learning. Pedagogies, v. 4, p. 164-195, 2009.

DELEUZE, G.; GUATTARI, F. Mil Platôs - capitalismo e esquizofrenia. 2. Ed. Rio de Janeiro: Ed. 34, 1995. 128p.

FELTRIN, T.; BATISTA, N. L. O uso de Tecnologias de Informação e de Comunicação por alunos de $6^{\circ}$ ano de uma escola de periferia como possibilidade pedagógica. Revista Percurso, Maringá, v. 9, n. 2, p. 47-65, 2017.

GARDNER, H. Cinco mentes para o futuro. 1. ed. Porto Alegre: Artmed, 2007. 160p.

MAIA, J. O. Novos híbridos letramentos em contexto de periferia. In: ROJO, R (Org.). Escola conectada: os multiletramentos e as TICs. São Paulo: Parábola, 2013. 216p.

RIZZATTI, M. A cartografia escolar e as inteligências múltiplas no ensino de Geografia: contribuições das geotecnologias no Ensino Fundamental. 2018. 144 f. Dissertação (Mestrado em Geografia) - Programa de Pós-Graduação em Geografia, Universidade Federal de Santa Maria, Santa Maria, 2018. 
SIMIELLI, M. E. R. Cartografia no ensino fundamental e médio. In: CARLOS, A. F. A. A. (Org.). Geografia em sala de aula. São Paulo: Contexto, 1999. cap. 7, p. 92-108.

Trabalho enviado em 11/02/2019

Trabalho aceito em 18/07/19 